\title{
JUBULA HUTCHINSIAE SUBSP. JAVANICA (HEPATICAE, JUBULACEAE): A GENUS AND SPECIES NEW FOR THAILAND
}

\author{
PHIANGPHAK SUKKHARAK
}

\begin{abstract}
Jubula hutchinsiae (Hook.) Dumort. subsp. javanica (Steph.) Verd. collected from the Khao Soi Dao wildlife sanctuary, Chanthaburi province, is a new genus and species record for Thailand. A brief description based on Thai material is provided, with illustrations.
\end{abstract}

Key words: liverwort, Chanthaburi province, Khao Soi Dao wildlife sanctuary, Asia, distribution

Phiangphak Sukkharak, Department of Biology, Faculty of Science, Burapha University, Chonburi 20131, Thailand; e-mail: phiangphak@buu.ac.th

\section{INTRODUCTION}

Jubula Dumort. (Jubulaceae) is a tropical-holarctic genus of seven species including two subspecies and two varieties, growing as epiphytes restricted to humid or damp sites, often near flowing water (Guerke 1978; Gradstein et al. 2001; Frey \& Stech 2009; Dey et al. 2011). None of them have been recorded from Thailand (Lai et al. 2008; Sukkharak \& Chantanaorrapint 2014). In a study of the bryophytes of the Khao Soi Dao wildlife sanctuary (Sukkharak et al. submitted), the first record of a Jubula species for Thailand was made. Jubula hutchinsiae (Hook.) Dumort. subsp. javanica (Steph.) Verd. is described and illustrated based on the Thai material in this paper. The specimen is kept in the Department of Biology, Faculty of Science, Burapha University.

\section{RESULTS AND DISCUSSION}

Jubula Dumort.

Comm. Bot.: 112. 1822. - TYPE: Jungermannia hutchinsiae Hook. [Jubula hutchinsiae (Hook.) Dumort.].

Jubula hutchinsiae (Hook.) Dumort. subsp. javanica (Steph.) Verd.

Fig. 1

Ann. Cryptog. Exot. 1: 216. 1928. Jubula javanica Steph., Sp. Hepat. 4: 688. 1991.
Plants with irregularly pinnate branches, green, without reddish pigmentation, up to $1.3 \mathrm{~cm}$ long $\times 1.2-1.4 \mathrm{~mm}$ wide, branches Frullania-type. Rhizoids in tufts from underleaf bases. Stems in cross section subelliptic in shape, 148-160 $\times$ 179-190 $\mu \mathrm{m}$ thick, composed of 29-32 epidermal cells surrounding 35-40 medullary cells in 7-8 layers, epidermal cells thick-walled, medullary cells larger and thinner-walled than epidermal cells. Leaves incubous, attached to the axis along a J-shaped insertion line; lobe ovate, $0.7-0.9 \times$ $0.3-0.5 \mathrm{~mm}$, apex acuminate, margins entire; cells isodiametric, marginal cells $7-15 \times 7-12 \mu \mathrm{m}$, median cells $15-20 \times 10-18 \mu \mathrm{m}$, basal cells $22-38$ $\times 17-25 \mu \mathrm{m}$, cells wall thin, trigones minute; oil bodies unknown; leaf lobule dimorphic, galeate or explanate, $170-185 \times 60-70 \mu \mathrm{m}$; stylus filiform, 4-5 cells long. Underleaves distant to slightly contiguous, suborbicular, $0.3-0.4 \times 0.3-0.4 \mathrm{~mm}$, bilobed to $1 / 2 \times$ their length, lobe apices acuminate, sinus narrowly to widely acute, margins entire. Gammae not seen. Autoicous. Androecia intercalary on lateral branches, bracts and bracteoles in 4-6 pairs. Gynoecia terminal with 1-2 innovations; lobe lanceolate, $1.2-1.5 \times 0.4-0.5 \mathrm{~mm}$, apex apiculate, margin entire; lobules lanceolate, $2 / 3 \times$ lobe length, apex apiculate; bracteoles ovate, $1-1.2$ $\times 0.3-0.4 \mathrm{~mm}$, bilobed to $2 / 3 \times$ their length, lobe 


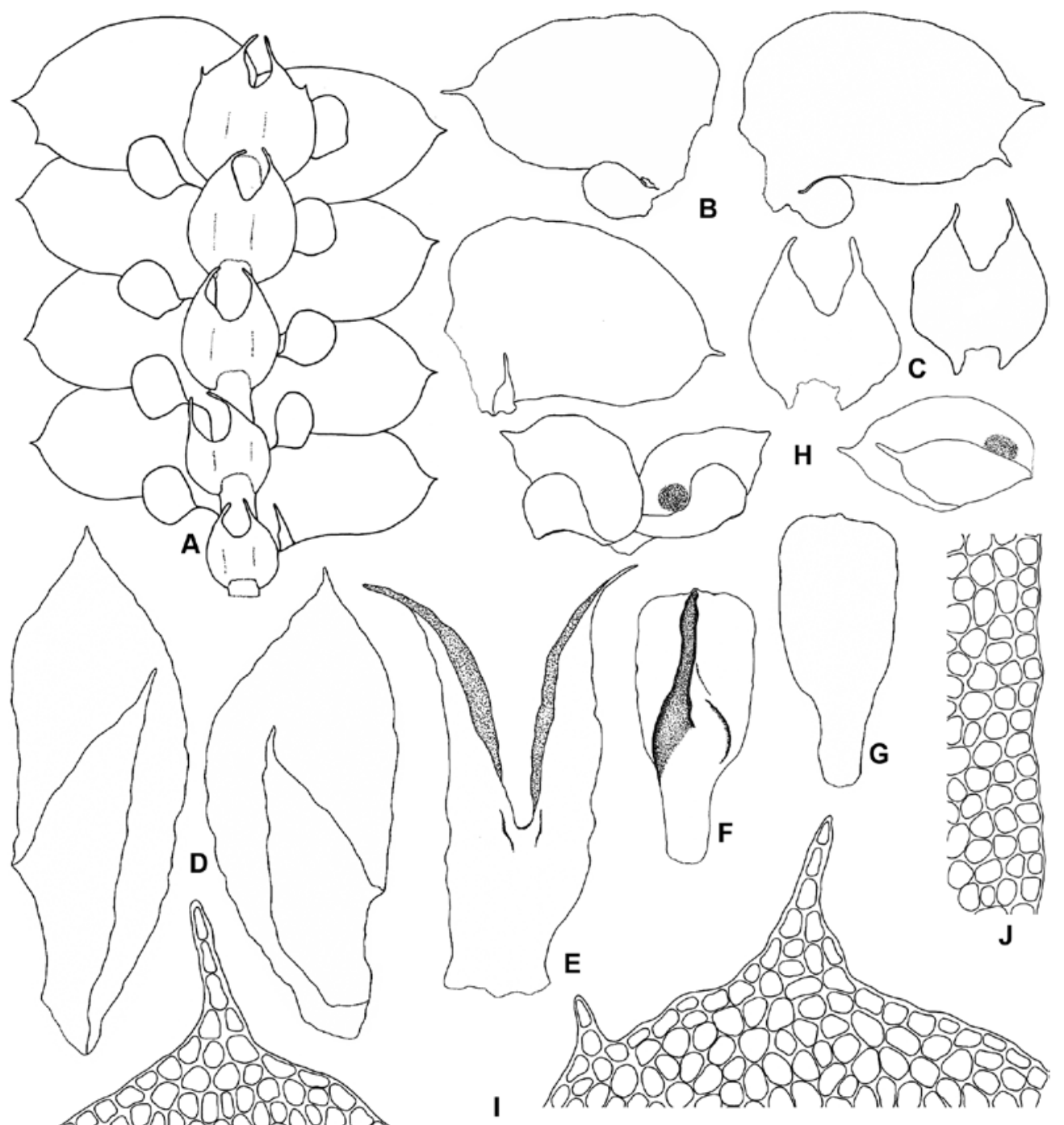

nonarnogurnonna

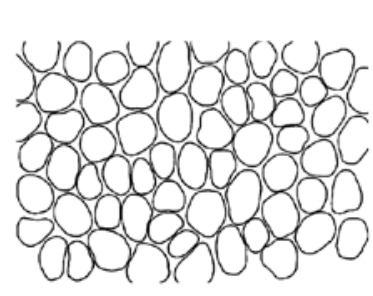

$\mathbf{K}$

A

$500 \mu \mathrm{m}$

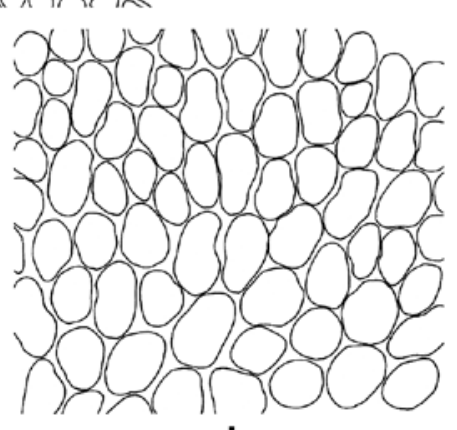

$\mathrm{L}$

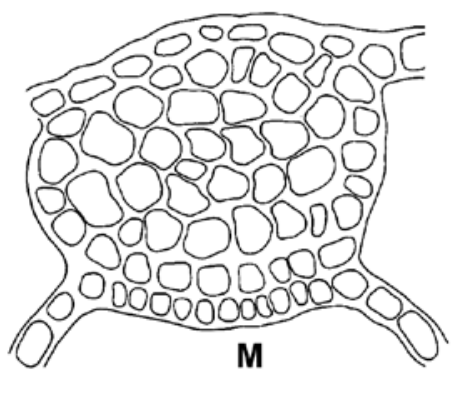


apices acuminate, sinus narrow, margins entire, central region gibbous. Perianths exserted to $1 / 2$, oblong, 1.7-2 × 0.7-1 mm, 3-keeled, margin entire; beak 30-38 $\mu \mathrm{m}, 2-3$ cells long. Sporophyte not seen.

SPECIMEN EXAMINED: THAILAND, KHAOO SoI DAO WILDLIFE SANCUARY, on bark of tree, 8 April 2012, Sukkharak et al. 340 (herbarium of Department of Biology, Burapha University).

ECOLOGY. Growing on bark in moist area.

DisTRIBUTION. Jubula hutchinsiae subsp. javanica is known from Peninsular India (Pócs et al. 2007), China (Pätsch et al. 2010), Korea (Katagiri et al. 2010; Choi et al. 2013), Japan (Katagiri et al. 2010), Taiwan (Wang et al. 2011), Vietnam (Pätsch et al. 2010), Malaysia (Pätsch et al. 2010), Indonesia (Gradstein 2011), and from Thailand.

The specimen of the new record is distinguished by its entire leaf lobe, bract, and bracteole margins and apiculate leaf apex. The recent discovery of Jubula hutchinsiae subsp. javanica is the first genus and species record for Thailand. It is an additional occurrence of the species, closing the gap in its range. It bears witness that the bryoflora of Thailand remains poorly known and that exciting discoveries may still be made in this floristically rich part of the world.

ACKNOWLEDGEMENTS. I am very grateful to the Department of National Parks, Wildlife and Plant Conservation for their kind permission to work and collect in the Khao Soi Dao wildlife sanctuary, Chanthaburi Province. Thanks are also due to Dr. Sahut Chantanaorrapint (Songkla, Thailand) for literature, and to Dr. Tomoyuki Katagiri (Hiroshima, Japan) and the anonymous reviewer for helpful suggestions on the manuscript. This study was supported by the Faculty of Science, Burapha University, Chonburi, Thailand.

\section{REFERENCES}

Choi S. S., BaKalin V. A. \& Sun B.-Y. 2013. Hepatics of Mt. Deogyu National Park, Republic of Korea. Botanica Pacifica 2: 63-71.

Dey M., Singh D. \& Singh D. K. 2011. Jubula pennsylvanica (Hepaticae: Jubulaceae) new to Asia. Taiwania 56: 66-70.

FREY W. \& STECH M. 2009. Marchantiophyta, Bryophyta, Anthocerotophyta. In: W. FREY (ed.), Syllabus of plant families - A. Engler's Syllabus der Pflanzenfamilien, 13th ed., Part 3. Bryophytes and seedless vascular plants, pp. 13-263. Schweizerbart, Stuttgart.

GRADSTEIN S. R. 2011. Guide to the liverworts and hornworts of Java. SEAMEO-BIOTROP, Bogor.

Gradstein S. R., Churchill S. P. \& Salazar A. N. 2001. Guide to the Bryophytes of Tropical America. Mem. New York Bot. Gard. 86: 1-577.

GUERKE W. R. 1978. A monograph of the genus Jubula Dumortier. Bryophyt. Biblioth. 17: 1-118.

Katagiri T., YAmaguchi T. \& Deguchi H. 2010. Taxonomic studies on the liverwort Jubula Dumort. (Marchantiophyta: Jubulaceae) in Japan and Taiwan. Hikobia 15: 463-472.

LAI M.-J., ZHU R.-L. \& CHANTANAORRAPINT S. 2008. Liverworts and hornwort of Thailand: an updated checklist and bryofloristic accounts. Ann. Bot. Fenn. 45: 321-341.

PÄTSCH R., HENTSCHEL J., LiNARES-PALOMINO R., ZHU R.-L. \& HEINRICHS J. 2010. Diversification and taxonomy of the liverwort Jubula Dumort. (Jungermanniopsida: Porellales) inferred from nuclear and chloroplast DNA sequences. Syst. Bot. 35: 6-12.

Pócs T., NaIR M. C., Rajesh K. P. \& Madhusoondanan P. V. 2007. Liverwort (Marchantiopsida) records from the Western Ghats (Kerala State, Peninsular India). Acta Bot. Hung. 49: 121-129.

SukKharaK P. \& ChAnTANAORRAPINT S. 2014. Bryophyte studies in Thailand: past, present, and future. Cryptog. Bryol. (in press).

WANG J., LAI M.-J. \& ZHU R.-L. 2011. Liverworts and hornworts of Taiwan: an updated checklist and floristic accounts. Ann. Bot. Fenn. 48: 369-395.

\section{Received 26 August 2013}

Fig. 1. Jubula hutchinsiae subsp. javanica (Steph.) Verd. A - portion of shoot, ventral view, B - leaves, ventral view, C - underleaves, D - female bracts, E - female bracteole, F - perianth, ventral view, G - perianth, dorsal view, $\mathrm{H}$ - male bracts, $\mathrm{I}$ - leaf apices, $\mathrm{J}$ - marginal cells of leaf lobe, $\mathrm{K}$ - median cells of leaf lobe, $\mathrm{L}$ - basal cells of leaf lobe, $\mathrm{M}$ - cross section of stem (all from Sukkharak et al. 340). 